Chromium (III) complexes of azo dye ligands: Synthesis, characterization, DNA binding and application studies

Nasir Abbas, Syed Ahmad Tirmizi, Ghulam Shabir, Aamer Saeed, Ghulam Hussain, Pervaiz Ali Channer, Rashid Saleem \& Muhammad Ayaz

To cite this article: Nasir Abbas, Syed Ahmad Tirmizi, Ghulam Shabir, Aamer Saeed, Ghulam Hussain, Pervaiz Ali Channer, Rashid Saleem \& Muhammad Ayaz (2017): Chromium (III) complexes of azo dye ligands: Synthesis, characterization, DNA binding and application studies, Inorganic and Nano-Metal Chemistry,

Accepted author version posted online: 30 Aug 2017.

Submit your article to this journal

III Article views: 2

Q View related articles ๘

View Crossmark data〔 


\title{
Chromium (III) Complexes of Azo Dye Ligands: Synthesis, Characterization, DNA
}

\section{Binding and Application Studies}

Nasir Abbas ${ }^{\mathrm{a}}$, Syed Ahmad Tirmizi ${ }^{\mathrm{a}}$, Ghulam Shabir ${ }^{\mathrm{a}}$, Aamer Saeed ${ }^{\mathrm{a}}$, Ghulam Hussain ${ }^{\mathrm{b}}$,

Pervaiz Ali Channer ${ }^{\mathrm{b}}$, Rashid Saleem ${ }^{\mathrm{c}}$, Muhammad Ayaz ${ }^{\mathrm{d}}$

${ }^{\mathrm{a}}$ Department of Chemistry, Quaid-I-Azam University, Islamabad 45320, Pakistan.

${ }^{\mathrm{b}}$ Department of Chemistry, Quaid-I-Azam University, Islamabad 45320, Pakistan.

${ }^{c}$ R\&D Manager Shafi Reso Chem Lahore Pakistan.

${ }^{\mathrm{d}}$ CECOS University of IT and Emerging Sciences, Hayatabad, Peshawar.

\section{Research Highlights}

- $\quad$ A series of metal complexes has been synthesized from 1-(p-sulphophenyl)-3-methyl-4amino pyrazolone with different phenol derivatives at high temperature for chromium.

- Investigated metal complexes have been applied on leather which exhibit high light fastness, wash fastness and rubbing fastness.

- DNA interaction has also been accomplished.

\begin{abstract}
Chromium (III) complexes of Azo dyes ligands envisaged on novel synthesized 4-Amino-1-( $p$ sulphophenyl)-3-methyl-5-pyrazolone diazonium salt coupled with different phenolic couplers appended on diverse substituents. The complexes have been characterized by elemental analysis,
\end{abstract}




\section{ACCEPTED MANUSCRIPT}

UV, FTIR and NMR studies. The DNA studies have been investigated for complexes by electronic absorption spectroscopy. The results have shown that chromium (III) complexes bind to DNA through intercalation mode. Synthesized Chromium complexes have been applied on leather to check their serviceability and they exhibited moderate to high values of light fastness and perspiration fastness (4-5).

\section{Graphical Abstract}

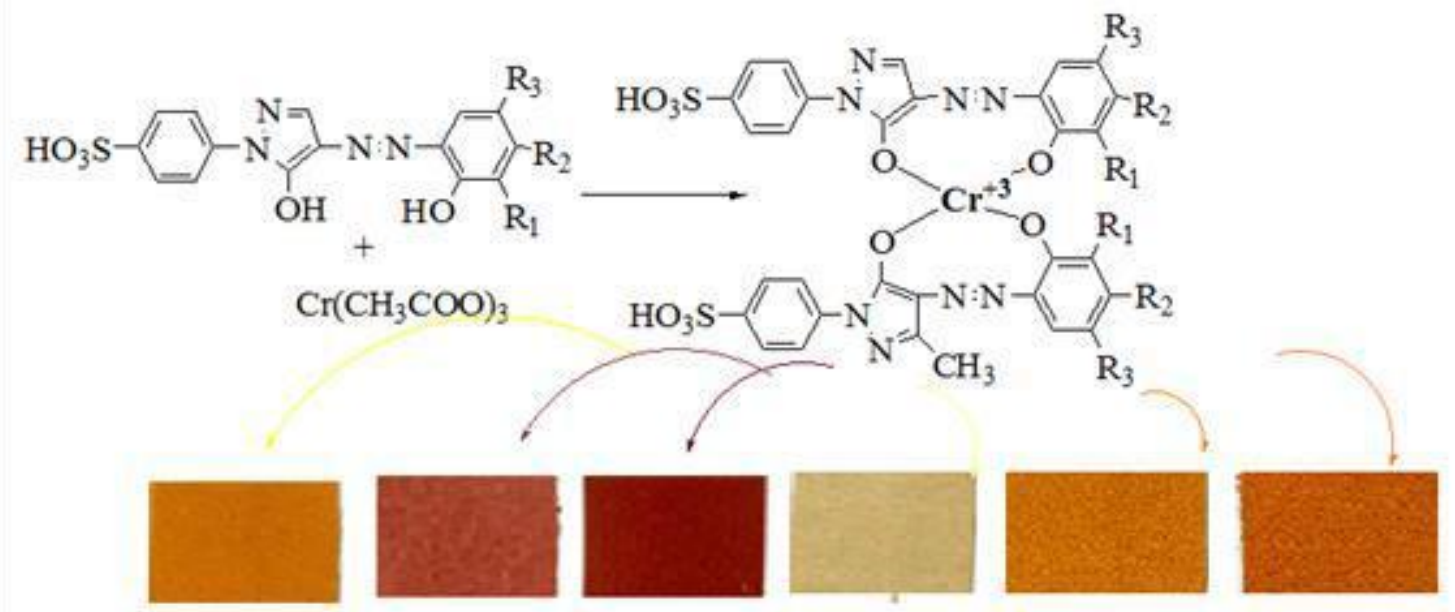

Key Words

Complexes, DNA binding, Intercalation mode, Electronic Spectroscopy 


\section{ACCEPTED MANUSCRIPT}

\section{Introduction}

Azo compounds are very important molecules and have attracted much attention in both academic and applied research [Nejati 2009]. Most azo dyes are prepared from Diazonium salts furthermore they constitute $60--70 \%$ of the industrial dyes used today. The obtained chromium complexed azo dyes are colored and have been widely used in many practical applications such as printing systems, coloring fibers, photo-electronic applications, optical storage technology as well as biological reactions and analytical chemistry [Vulpes 2009]. Also the importance of heterocyclic azo dyes and their metal complexes may stem from their biological activity [Gaber 2003]. Metal complexes of azo dyes ligand have extensive applications in electro-photographic toners as charge controlling agents, developers in power coating materials and in electrostatic separation process [Khalid 2015]. Azo derivatives and their complexes are very important pigments for synthetic leather and vinyl polymers [Nejati 2009]. Many azo dyes have been utilized as chromogenic reagents for colorimetric determinations and as indicators for complexometric titrations [sarigul 2016]. The azo metal complexes were applied on leather and their color fastness studies were performed. http://learnrnd.com/detail.php?id=Biowarfare_and_Germwarfare

\section{Experimental.}

\subsection{Materials and reagents.}

All the chemicals are reagents used were analytical grade. Melting points were determined in open capillary tube on Gallencamp apparatus.UV of all the samples were determined in water using Shimadzu UV-1700 spectrophotometer. FT-IR spectra were run in Cary 630, Agilent Technologies, USA. The formation of complexes were analyzed progressively on silica gel TLC 


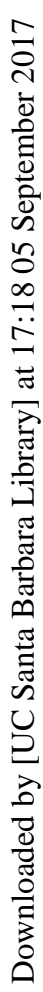




\section{ACCEPTED MANUSCRIPT}

using two different eluting solvents. The solvent systems were petroleum ether: chloroform $(9: 1, \mathrm{~V} / \mathrm{V})$ and chloroform and methanol $(9: 1, \mathrm{~V} / \mathrm{V})$. Under UV lamp the spots were visualized and their Rf values were compared. Fastness properties were obtained in accordance with BS 1006-- 1978. AtlasCrock meter in accordance with AATCC TM 8--1961 was employed to check the rubbing fastness properties. In accordance to

ISO: 765--1979 the wash fastness were observed (Sakuma et al. 2012). http://learnrnd.com/detail.php?id=Age_Effects_on_Brain_with_Symptoms_and_their_Solutions

\subsection{General Procedure for the Synthesis of 1-( $p$-Sulphophenyl)-3-methyl-4-amino} pyrazolone based Acid Dyes

Synthesis of acid dyes and their metal complexes involves three step procedure which is as follows:

\section{a. Nitrosation of 1-(p-Sulphophenyl-3-methyl-4-amino pyrazolone (SPMP)}

1-(p-methylphenyl-3-methyl-5-pyrazolone (1) $\left(25.4 \mathrm{~g}, \quad 0.1\right.$ mol) was suspended in $\mathrm{H}_{2} \mathrm{O} \quad(250 \mathrm{ml})$. Hydrochloric acid $(45 \mathrm{ml})$ was added to this well stirred suspension. The reaction mixture was cooled to 0-$5 .{ }^{\circ} \mathrm{C}$ in an ice bath. A solution of $\mathrm{NaNO}_{2}(6.9 . \mathrm{g}, 0.1 \mathrm{~mol})$ in $\mathrm{H}_{2} \mathrm{O}(25 \mathrm{ml})$ previously cooled to $0{ }^{\circ} \mathrm{C}$, was then added over a period of half hour with stirring. The stirring was continued for an hour more maintaining the same temperature, with a positive test for nitrous acid. Later on the excess of nitrous acid was destroyed with required amount of sulphamic acid. The Nitroso compound (Tautomeric form is called Oxime) was filtered after salting out. Then oxime was reduced by stirring in $200 \mathrm{ml}$ water containing $85 \mathrm{ml} \mathrm{HCl}$ and $23 \mathrm{~g}$ Zinc metal at boiling for $4 \mathrm{~h}$. At the completion of reaction, $\mathrm{pH}$ of the reaction mixture 


\section{ACCEPTED MANUSCRIPT}

was raised to 9 with $6 \mathrm{~N} \mathrm{NaOH}$, and precipitated the 1-(p-sulphophenyl-3-methyl-4-amino pyrazolones.

\section{b. Diazotization and Coupling with Phenol Derivatives}

To the well stirred aqueous of 1-( $p$-sulphophenyl-3-methyl-4- amino pyrazolone $(2.69 \mathrm{~g})$ sodium nitrite solution $(0.7 \mathrm{~g}$ in $2 \mathrm{~mL}$ water $)$ was added after the addition of $\mathrm{Conc} . \mathrm{HCl}$ $(3.5 \mathrm{~mL})$ at $0--5{ }^{\circ} \mathrm{C}$. In order to obtain the diazonium salt of 1-(p-sulphophenyl)-3-methyl-4amino pyrazolone, the reaction mixture was stirred for $1 \mathrm{~h}$ at the temperature aforesaid. A variety of dyes were prepared by coupling various compounds as couplers with prepared diazonium salt. Ipso-facto $1.285 \mathrm{~g}(0.010 \mathrm{~mol})$ 4-Chlorophenol (5 a) was dissolved in $200 \mathrm{~mL}$ water containing $0.45 \mathrm{~g} \mathrm{NaOH}$ and coupled with prepared diazo. The coupling was facilitated using sodium carbonate as an acid binding agent. The reaction mixture was given 4-$5 \mathrm{~h}$ to complete the coupling at $30--35{ }^{\circ} \mathrm{C}$. The dye was cooled to room temperature. Its $\mathrm{pH}$ was reduced to 4.5 by $\mathrm{HCl}$ and filtered. The cake was dried in oven at $70--75{ }^{\circ} \mathrm{C}$ till constant weight. By adopting the same procedure other dyes $6 \mathrm{~b}-\mathrm{f}$ were prepared from couplers $5 \mathrm{~b}-\mathrm{f}$ as shown in (scheme-1).

\section{c. Metallization of Acid Dyes.}

For the synthesis of Chromium complex $\mathrm{pH}$ of $25 \mathrm{~mL}(0.005 \mathrm{~mole})$ of dye $6 \mathrm{a}$ was reduced to 6.5 with $\mathrm{HCl}$. Then it was heated to $70^{\circ} \mathrm{C}$ and to it $5 \mathrm{ml}\left(0.005\right.$ mole $\left.\mathrm{Cr}^{3+}\right)$ solution of chromium acetate $\mathrm{Cr}\left(\mathrm{CH}_{3} \mathrm{COO}\right)_{3}$ was added drop wise. Mixing and heating at this temperature was continued for further 1.0 hour till the metallization was completed, as shown by the comparative 


\section{ACCEPTED MANUSCRIPT}

TLC. The dye was cooled to room temperature; its $\mathrm{pH}$ was reduced to 1.0 with conc. $\mathrm{HCl}$. Then it was salted out with sodium chloride, filtered and dried in oven at $70{ }^{\circ} \mathrm{C}$ till constant weight.

In this way complexes 7 a-f were synthesized from respective dye ligands whose physical and spectroscopic data is as follows

\section{6 a $\left(\mathrm{C}_{16} \mathrm{H}_{13} \mathrm{ClN}_{4} \mathrm{O}_{5} \mathrm{~S}\right)$}

Orange, $(76 \%) \lambda_{\max }(\mathrm{nm}): 460$. FTIR $\left(\mathrm{KBr}, \mathrm{cm}^{-1}\right) v_{\max }: 3255$ (OH str.), 3050 (C = C-H str.), 2927

$\left(\mathrm{CH}_{2}\right.$ str. $), 1653$ (C = O str.), 1595, $1541(\mathrm{C}=\mathrm{C}$ aromatic, $\mathrm{C}=\mathrm{N}), 1498(\mathrm{~N}=\mathrm{N}$ str. $), 1422,1340$

( $\mathrm{SO}_{3} \mathrm{H}$ str., $\mathrm{CH}_{2}$ bend.), 1236, 1155 (C-C, C-O str.), 1000 ( $\mathrm{S}=\mathrm{O}$ str.), 833 (Ar-H), 790(C-Cl

str.). ${ }^{1} \mathrm{HNMR}\left(300 \mathrm{MHz}, \mathrm{DMSO}_{6}\right) \delta: 8.07(1 \mathrm{H}, \mathrm{d} J=2.35 \mathrm{~Hz}), 7.95(2 \mathrm{H}, \mathrm{d} J=8.6 \mathrm{~Hz})$,

7.83-7.90 (1 $\mathrm{H}, \mathrm{m}), 7.68(2 \mathrm{H}, \mathrm{d} J=8.6 \mathrm{~Hz}), 6.65(1 \mathrm{H}, \mathrm{d}, J=9.1 \mathrm{~Hz}), 2.20(3 . \mathrm{H}, \mathrm{s}) .{ }^{13} \mathrm{C}-$

NMR (75 MHzDMSO-d 6 ) $\delta(\mathrm{ppm}): 158.54,156.64,147.93,147.37,143.21,139.93,125.43$,

124.41, 119.45, 118.06, 116.22 12.45. Anal. Calcd. For $\mathbf{C}_{\mathbf{1 6}} \mathbf{H}_{\mathbf{1 3}} \mathbf{C l N}_{\mathbf{4}} \mathbf{O}_{\mathbf{5}} \mathbf{S}: \mathrm{C}, 47.01 ; \mathrm{H}, 3.21 ; \mathbf{N}$, 13.71; S, 7.84 Found: C, 47.05; H, 3.30; N, 13.59; S, 7.79.

\section{$6 \mathrm{~b}\left(\mathrm{C}_{16} \mathrm{H}_{13} \mathrm{~N}_{5} \mathrm{O}_{7} \mathrm{~S}\right)$}

Dark Brown, (83\%). $\lambda_{\max }(\mathrm{nm})$ : 480. FTIR (KBr, $\left.\mathrm{cm}^{-1}\right) v_{\max }: 3388$ (OH str.), $2924\left(\mathrm{CH}_{2}\right.$ str.), $1666(\mathrm{C}=\mathrm{C}$ str. $), 1593(\mathrm{C}=\mathrm{C}$ aromatic, $\mathrm{C}=\mathrm{C}), 1498,1476\left(\mathrm{~N}=\mathrm{N}, \mathrm{NO}_{2}\right.$ str. $), 1267,1172(\mathrm{C}-\mathrm{O}$ str.), 1034 (C-OC str.), 821 (Ar-H). ${ }^{1}$ HNMR (300 MHz, DMSO-d 6 ) $\delta: 8.15$ (1 $\mathrm{H}, \mathrm{d} J=$ $2.4 \mathrm{~Hz}), 7.942(2 \mathrm{H}, \mathrm{d} J=8.7 \mathrm{~Hz}), 7.81-7.92(1 \mathrm{H}, \mathrm{m}), 7.65(2 \mathrm{H}, \mathrm{d} J=8.7 \mathrm{~Hz}), 6.38$

$(1 \mathrm{H}, \mathrm{d}, J=9.3 \mathrm{~Hz}), 2.27(3 \mathrm{H}, \mathrm{s}) .{ }^{13} \mathrm{C}-\mathrm{NMR}(75 \mathrm{MHz}$ DMSO-d 6 ) $\delta(\mathrm{ppm}): 158.0,155.28$, 148.32, 147.57, 144.58, 138.72, 128.18 126.86, 126.24, 118.19, 117.06, 116.17, 12.14. Anal. 


\section{ACCEPTED MANUSCRIPT}

Calcd. For $\mathbf{C}_{16} \mathbf{H}_{13} \mathbf{N}_{5} \mathbf{O}_{7} \mathbf{S}:$ C, 45.83; H, 3.12; N, 16.70, S, 7.64; Found: C, 45.78; H, 3.20; N, $16.58, \mathrm{~S}, 7.57$.

\section{$6 \mathrm{c}\left(\mathrm{C}_{16} \mathrm{H}_{14} \mathrm{~N}_{4} \mathrm{O}_{8} \mathrm{~S}_{2}\right)$}

Orange, (84\%). $\lambda_{\max }(\mathrm{nm}): 460$. FTIR (KBr, $\left.\mathrm{cm}^{-1}\right) v_{\text {max }}: 3389$ (OH str), 3086 (C = C-H str.), 1638 ( $\mathrm{N}-\mathrm{H}$ bend.), 1619, $1597\left(\mathrm{C}=\mathrm{C}\right.$ aromatic), $1541\left(\mathrm{~N}=\mathrm{N}\right.$ str.), 1500 ( $\mathrm{N}-\mathrm{Hb}$ bend.), $1340\left(\mathrm{SO}_{3} \mathrm{H}\right.$, $\mathrm{CH}_{2}$ str.), 1185 (C-O str.), 818 (Ar-H). ${ }^{1} \mathrm{HNMR}\left(300 \% \mathrm{MHz}, \mathrm{DMSO}_{\mathrm{d}}\right.$ ) $\delta: 11.87$ (1 $\left.\mathrm{H}, \mathrm{s}, \mathrm{O}-\mathrm{H}\right)$, $8.10(1 \mathrm{H}, \mathrm{d} J=2.6 \mathrm{~Hz}), 7.93(2 \mathrm{H}, \mathrm{d} J=8.6 \mathrm{~Hz}), 7.79-7.90(1 \mathrm{H}, \mathrm{m}), 7.67(2 \mathrm{H}, \mathrm{d} J=$ $8.6 \mathrm{~Hz}), 6.90\left(1 \mathrm{H}, \mathrm{s}, \mathrm{SO}_{3} \mathrm{H}\right), 6.58(1 \mathrm{H}, \mathrm{d}, J=9.5 \% \mathrm{~Hz}), 2.27(3 \mathrm{H}, \mathrm{s}) .{ }^{13} \mathrm{C}-\mathrm{NMR}(75$ MHzDMSO-d 6 ) $\delta(\mathrm{ppm}): 159.12,156.48,147.72,147.17,145.23,141.33,138.62,125.68$ 124.42, 117.19, 116.96, 116.43 11.81. Anal. Calcd. For $\mathbf{C}_{\mathbf{1 6}} \mathbf{H}_{\mathbf{1 4}} \mathbf{N}_{\mathbf{4}} \mathbf{O}_{\mathbf{8}} \mathbf{S}_{\mathbf{2}}$ : C, 42.29; H, 3.11; N, 12.33, S: 14.11 Found: C, 42.24; H, 3.20; N, 12.21, S: 14.04 .

\section{$6 \mathrm{~d}\left(\mathrm{C}_{16} \mathrm{H}_{13} \mathrm{~N}_{5} \mathrm{O}_{10} \mathrm{~S}_{2}\right)$}

Orange, (81\%). $\lambda_{\max }(\mathrm{nm}): 520$. FTIR $\left(\mathrm{KBr}, \mathrm{cm}^{-1}\right) v_{\max }: 3449$ (OH str.), $3050(\mathrm{C}=\mathrm{C}-\mathrm{H}$ str. $)$, $1653(\mathrm{C}=\mathrm{C}$ str. $\mathrm{NH}$ bend $), 1619,1541(\mathrm{C}=\mathrm{C}$ aromatic $), 1498(\mathrm{~N}=\mathrm{N}$ str. $), 1338\left(\mathrm{SO}_{3} \mathrm{H}, \mathrm{CH}_{2}\right.$ str.), 1183 (C-O str.), 1008 ( $\mathrm{S}=\mathrm{O}), 840$ (Ar-H). ${ }^{1} \mathrm{HNMR}\left(300 \mathrm{MHz}, \mathrm{DMSO}-\mathrm{d}_{6}\right) \delta: 11.33$ (1 $\mathrm{H}, \mathrm{s}, \mathrm{O}-\mathrm{H}), 8.15(1 \mathrm{H}, \mathrm{d} J=2.4 \mathrm{~Hz}), 7.99(1 \mathrm{H}, \mathrm{d} J=2.4 \mathrm{~Hz}), 7.922(2 \mathrm{H}, \mathrm{d} J=$ $8.7 \mathrm{~Hz}), 7.63(2 \mathrm{H}, \mathrm{d} J=8.7 \mathrm{~Hz}), 2.23(3 \mathrm{H}, \mathrm{s}) .{ }^{13} \mathrm{C}-\mathrm{NMR}(75 \mathrm{MHz}$ DMSO-d 6$) \delta(\mathrm{ppm})$ : $157.05,156.28,149.25,147.63,144.28,142.76,140.92,127.16,125.54,119.19,116.56,115.20$ 12.14.Anal. Calcd. For $\mathbf{C}_{\mathbf{1 6}} \mathbf{H}_{\mathbf{1 3}} \mathbf{N}_{\mathbf{5}} \mathbf{O}_{\mathbf{1 0}} \mathbf{S}_{\mathbf{2}}: \mathrm{C}, 38.48 ; \mathrm{H}, 2.62 ; \mathrm{N}, 14.02 ; \mathrm{S}, 12.84$; Found:C, 38.37; H, 2.69; N, 13.96; S, 12.88 .

$6 e\left(\mathrm{C}_{32} \mathrm{H}_{26} \mathrm{~N}_{8} \mathrm{O}_{12} \mathrm{~S}_{3}\right)$ 


\section{ACCEPTED MANUSCRIPT}

Orange, (80\%). $\lambda_{\max }(\mathrm{nm}): 420$. FTIR $\left(\mathrm{KBr}, \mathrm{cm}^{-1}\right) v_{\max }: 3395$ (, OH, NH str.), $3050(\mathrm{C}=\mathrm{C}-\mathrm{H}$ str.), 2926 ( $\mathrm{CH}_{2}$ str.), 1619, 1586 ( $\mathrm{C}=\mathrm{C}$ aromatic, $\mathrm{C}=\mathrm{N}$ ), 1498 ( $\mathrm{N}=\mathrm{N}$ str.), 1125 (C-O str.), 1008 $(\mathrm{S}=\mathrm{O}), 872(\mathrm{Ar}-\mathrm{H}) .{ }^{1} \mathrm{HNMR}\left(300 \mathrm{MHz}, \mathrm{DMSO}_{\mathrm{d}}\right) \delta: 11.67(1 \mathrm{H}, \mathrm{s}, \mathrm{O}-\mathrm{H}), 7.91(2 \mathrm{H}, \mathrm{d}$ $J=8.7 \mathrm{~Hz}), 7.81-7.92(1 \mathrm{H}, \mathrm{m}), 7.69(2 \mathrm{H}, \mathrm{d} J=8.7 \mathrm{~Hz}), 6.90(1 \mathrm{H}, \mathrm{d}, J=9.4 \mathrm{~Hz}), 6.78$

(1 $\mathrm{H}, \mathrm{s}), 6.62\left(1 \mathrm{H}, \mathrm{s}, \mathrm{SO}_{3} \mathrm{H}\right), 6.59(1 \mathrm{H}, \mathrm{d}, J=9.4 \mathrm{~Hz}), 2.51(3 \mathrm{H}, \mathrm{s}), 1.469(6 \mathrm{H}, \mathrm{s}) .{ }^{13} \mathrm{C}-$ NMR (75 MHz, DMSO-d 6 ) $\delta$ (ppm): 157.56, 154.89, 148.97, 154.64, 144.47, 143.44, 142.29, 141.31, 138.88, 137.90, 129.96, 128.05, 127.74, 126.78, 119.85, 118.63, 117.64, 115.79, 115.64, 115.13, 115.02, 41.19, 30.83, 11.59. Anal. Calcd. For $\mathbf{C}_{\mathbf{3 2}} \mathbf{H}_{\mathbf{2} 6} \mathbf{N}_{\mathbf{8}} \mathbf{O}_{12} \mathbf{S}_{3}: \mathrm{C}, 47.40 ; \mathrm{H}, 3.23 ; \mathbf{N}$, 13.82; S, 11.86; Found: C, 47.46; H, 3.31; N, 13.56; S, 11.80.

\section{6f $\left(\mathrm{C}_{35} \mathrm{H}_{32} \mathrm{~N}_{8} \mathrm{O}_{10} \mathrm{~S}_{2}\right)$}

Brown, (83\%). $\lambda_{\max }$ (nm): 450. FTIR (KBr, cm $\left.{ }^{-1}\right) v_{\max }$ : 3464 (OH, NH str.), $2963\left(\mathrm{CH}_{2}\right.$ str.), 1653, 1593 ( $\mathrm{C}=\mathrm{C}$ aromatic), 1490( $\mathrm{N}=\mathrm{N}$ str.), 1338 ( $\mathrm{SO}_{3} \mathrm{H}$ str.), 1213, 1153, 1120 (C-C str.), $1002(\mathrm{~S}=\mathrm{O}), 872(\mathrm{Ar}-\mathrm{H}) .{ }^{1} \mathrm{H}-\mathrm{NMR}\left(300 \mathrm{MHz}, \mathrm{DMSO}_{6}\right)$ ) $: 11.30(1 \mathrm{H}, \mathrm{s}, \mathrm{O}-\mathrm{H}), 7.94(2 \mathrm{H}$, $\mathrm{d} J=8.7 \mathrm{~Hz}), 7.82-7.93(1 \mathrm{H}, \mathrm{m}), 7.67(2 \mathrm{H}, \mathrm{d} J=8.7 \mathrm{~Hz}), 6.98(1 \mathrm{H}, \mathrm{d}, J=9.4 \mathrm{~Hz}), 6.81$ $(1 \mathrm{H}, \mathrm{s}), 6.58(1 \mathrm{H}, \mathrm{d}, J=9.4 \mathrm{~Hz}), 6.42\left(1 \mathrm{H}, \mathrm{s}, \mathrm{SO}_{3} \mathrm{H}\right), 2.47(3 \mathrm{H}, \mathrm{s}) .{ }^{13} \mathrm{C}-\mathrm{NMR}(75 \mathrm{MHz}$, DMSO-d $\left._{6}\right) \delta$ (ppm): $158.77,155.9,147.61,145.61,143.86,143.25,141.63,139.81,136.75$, 130.25, 127.91, 125.78, 119.80, 118.31, 116.73, 115.94, 115.23, 11.59. Anal. Calcd. For $\mathbf{C}_{35} \mathbf{H}_{32} \mathbf{N}_{8} \mathrm{O}_{10} \mathbf{S}_{2}:$ C, 53.29; H, 4.09; N, 14.21; S, 8.13; Found: C, 53.35; H, 4.13; N, 14.04; S, 8.20 .

\section{7 a $\left(\mathrm{C}_{32} \mathrm{H}_{23} \mathrm{Cl}_{2} \mathrm{CrN}_{8} \mathrm{O}_{10} \mathrm{~S}_{2}\right)$}

Maroon/Yellowish Red, (66\%) $\lambda_{\max }(\mathrm{nm}): 464$. FTIR $\left(\mathrm{KBr}, \mathrm{cm}^{-1}\right) v_{\max }: 3050$ (C = C-H str.), 1642 $(\mathrm{C}=\mathrm{O}$ str. $), 1583,1537(\mathrm{C}=\mathrm{C}$ aromatic, $\mathrm{C}=\mathrm{N}), 1485(\mathrm{~N}=\mathrm{N}$ str. $), 1417,1335\left(\mathrm{SO}_{3} \mathrm{H}\right.$ str., $\mathrm{CH}_{2}$ 


\section{ACCEPTED MANUSCRIPT}

bend.), 1226, 1145 (C-C, C-O str.), 1012 (S = O str.), 830 (Ar-H), 785(C-Cl str.). Anal. Calcd.

For $\mathbf{C}_{16} \mathbf{H}_{13} \mathrm{ClN}_{\mathbf{4}} \mathbf{O}_{5} \mathrm{~S}: \mathrm{C}, 44.35 ; \mathrm{H}, 2.68 ; \mathrm{N}, 12.93 ; \mathrm{S}, 7.40 ;$ Found:C, 44.43; H, 2.58; N, 12.83; S, 7.50 .

\section{$7 \mathrm{~b}\left(\mathrm{C}_{32} \mathrm{H}_{23} \mathrm{CrN}_{10} \mathrm{O}_{14} \mathrm{~S}_{2}\right)$}

Reddish orange, $(73 \%) \cdot \lambda_{\max }(\mathrm{nm}): 483$. FTIR $\left(\mathrm{KBr}, \mathrm{cm}^{-1}\right) v_{\max }: 1676(\mathrm{C}=\mathrm{C}$ str. $), 1587(\mathrm{C}=\mathrm{C}$ aromatic, $\mathrm{C}=\mathrm{C}$ ), 1495, $1471\left(\mathrm{~N}=\mathrm{N}, \mathrm{NO}_{2}\right.$ str.), 1267, 1172 (C-O str.), 1039 (C-OC str.), 829 (Ar-H). Anal. Calcd. For $\mathbf{C}_{\mathbf{1 6}} \mathbf{H}_{13} \mathbf{N}_{\mathbf{5}} \mathbf{O}_{7} \mathbf{S}:$ C, 43.30; H, 2.61; N, 15.78; S, 7.22; Found:C, 43.20; H, 2.70; N, 15.89; S, 7.34.

\section{$7 \mathrm{c}\left(\mathrm{C}_{32} \mathrm{H}_{25} \mathrm{CrN}_{8} \mathrm{O}_{16} \mathrm{~S}_{4}\right)$}

Brown/Reddish orange, (74\%). $\lambda_{\max }(\mathrm{nm}): 489$. FTIR $\left(\mathrm{KBr}, \mathrm{cm}^{-1}\right) v_{\max }: 3076$ (C = C-H str.), 1623

(N-H bend.), 1621, 1599 ( $\mathrm{C}=\mathrm{C}$ aromatic), $1539\left(\mathrm{~N}=\mathrm{N}\right.$ str.), $1498\left(\mathrm{~N}-\mathrm{Hbend}\right.$.), $1354\left(\mathrm{SO}_{3} \mathrm{H}\right.$, $\mathrm{CH}_{2}$ str.), 1174 (C-O str.), 814 (Ar-H). Anal. Calcd. For $\mathbf{C}_{\mathbf{1 6}} \mathbf{H}_{\mathbf{1 4}} \mathbf{N}_{\mathbf{4}} \mathbf{O}_{\mathbf{8}} \mathbf{S}_{\mathbf{2}}: \mathbf{C}, 40.13 ; \mathrm{H}, 2.63 ; \mathrm{N}$, 11.70; S, 13.39; Found:C, 40.33; H, 2.54; N, 11.73; S, 13.41.

\section{$7 \mathrm{~d}\left(\mathrm{C}_{32} \mathrm{H}_{23} \mathrm{CrN}_{10} \mathrm{O}_{20} \mathrm{~S}_{4}\right)$}

Brown/Reddish orange, (81\%). $\lambda_{\max }(\mathrm{nm}): 505$. FTIR $\left(\mathrm{KBr}, \mathrm{cm}^{-1}\right) v_{\max }: 3056(\mathrm{C}=\mathrm{C}-\mathrm{H}$ str. $), 1648$ $(\mathrm{C}=\mathrm{C}$ str. $\mathrm{NH}$ bend $), 1622,1539(\mathrm{C}=\mathrm{C}$ aromatic $), 1492(\mathrm{~N}=\mathrm{N}$ str. $), 1343\left(\mathrm{SO}_{3} \mathrm{H}.\right), 1173(\mathrm{C}-\mathrm{O}$ str.), 1010 ( $(\mathrm{S}=\mathrm{O}), 856$ (Ar-H). Anal. Calcd. $\mathbf{C}_{\mathbf{3 2}} \mathbf{H}_{\mathbf{2 3}} \mathbf{C r N}_{\mathbf{1 0}} \mathbf{O}_{\mathbf{2 0}} \mathbf{S}_{\mathbf{4}} \mathrm{C}, 36.68 ; \mathrm{H}, 2.21 ; \mathrm{N}, 13.37 ; \mathrm{S}$, 12.24; Found: C, 36.73; H, 2.27; N, 13.39; S, 12.20.

$7 \mathrm{e}\left(\mathrm{C}_{64} \mathrm{H}_{46} \mathrm{Cr}_{2} \mathrm{~N}_{16} \mathrm{O}_{24} \mathrm{~S}_{6}\right)$ 


\section{ACCEPTED MANUSCRIPT}

Beige/Yellowish orange, (70\%). $\lambda_{\max }(\mathrm{nm}): 584$. FTIR $\left(\mathrm{KBr}, \mathrm{cm}^{-1}\right) v_{\max }: 3048(\mathrm{C}=\mathrm{C}-\mathrm{H}$ str. $)$, 1621, $1574(\mathrm{C}=\mathrm{C}$ aromatic, $\mathrm{C}=\mathrm{N}), 1496(\mathrm{~N}=\mathrm{N}$ str. $), 1122(\mathrm{C}-\mathrm{O}$ str. $), 1011(\mathrm{~S}=\mathrm{O}), 869(\mathrm{Ar}-$ H). Anal. Calcd. For $\mathbf{C}_{\mathbf{3 2}} \mathbf{H}_{\mathbf{2}} \mathbf{N}_{\mathbf{8}} \mathbf{O}_{\mathbf{1 2}} \mathbf{S}_{3}: \mathrm{C}, 47.48 ; \mathrm{H}, 3.27 ; \mathrm{N}, 13.86 ; \mathrm{S}, 11.85$; Found: C, 47.44; H, 3.33; N, 13.52; S, 11.81.

$7 \mathrm{f}\left(\mathrm{C}_{70} \mathrm{H}_{58} \mathrm{Cr}_{2} \mathrm{~N}_{16} \mathrm{O}_{20} \mathrm{~S}_{4}\right)$

Tan/Reddish orange, $(73 \%) . \lambda_{\max }(\mathrm{nm}): 479$. FTIR $\left(\mathrm{KBr}, \mathrm{cm}^{-1}\right) v_{\max }: 1645,1589(\mathrm{C}=\mathrm{C}$ aromatic), 1485( $\mathrm{N}=\mathrm{N}$ str.), 1341 ( $\mathrm{SO}_{3} \mathrm{H}$ str.), 1210, 1150, 1118 (C-C str.), 999 ( $\left.\mathrm{S}=\mathrm{O}\right), 875$

(Ar-H). Anal. Calcd. For $\mathbf{C}_{\mathbf{3 5}} \mathbf{H}_{\mathbf{3 2}} \mathbf{N}_{\mathbf{8}} \mathbf{O}_{\mathbf{1 0}} \mathbf{S}_{\mathbf{2}}$ : C, 45.81; H, 3.02; N, 18.53; S, 12.34. Found: C, 45.85; H, 3.09; N, 18.56; S, 12.38.

\subsection{Dyeing Method.}

Dye solution $(10 \mathrm{ml}, 0.4 \% \mathrm{w} / \mathrm{v})$ was taken in a dye-bath. The $\mathrm{pH}$ of the dye-bath was adjusted to 6.5 by adding acetic acid solution $(1.0 \mathrm{ml} .10 \% \mathrm{w} / \mathrm{v})$ solution. The total volume of the dyebath was adjusted to $100 \mathrm{ml}$ by adding required amount of water. The leather swatches were immersed into the dye-bath with stirring. The content of the dye-bath was stirred for $1 \mathrm{~h}$ at $25--$ $30^{\circ} \mathrm{C}$. The temperature was then gradually raised to $55^{\circ} \mathrm{C}$ over period of half hour and this temperature was maintained for one hour. The dye-bath was kept rotating during the process of dyeing. Then $2.0 \mathrm{ml}$ formic acid was added to adjust $\mathrm{pH}$ to 2.0 for dye fixation. After this, the spent dye liquor was taken in $250 \mathrm{ml}$ volumetric flask. The swatches were washed with cold water and the combined solution of dye liquor and washings was then further diluted to $250 \mathrm{ml}$ with water. In order to find out the exhaustion of dye on leather the absorbance of the solutions were recorded. The dyed swatches were dried and mounted on shade card. A weighed amount of 


\section{ACCEPTED MANUSCRIPT}

leather swatch was stirred in boiling acidified pyridine which dissolves the unfixed dye from swatch and from the absorbance of this solution percentage fixation was checked.

\subsection{DNA binding.}

The concentrations of the complexes and DNA were determined spectroscopically using molar extinction co-efficient. The DNA binding experiments were performed in distilled Water using $2 \%$ solution of metal complexes. The concentration of the DNA was determined from the

absorption intensity at $261.5 \mathrm{~nm}$ with a $\varepsilon$ value (Jayaseelan et al, 2011) of $6600 \mathrm{M}^{-1} \mathrm{~cm}^{-1}$. Experiments were performed by using different concentration of SS Fish Salmon sperm DNA $[10,20,30$ up to $100 \mu \mathrm{M}]$, keeping the concentration of the complex constant, with due correction for the absorbance of the SS Fish Salmon sperm DNA itself. Before recording the spectra the samples were equilibrated.

$\underline{\text { http://learnrnd.com/detail.php?id=3D_and_4D_Printed_Houses_and_its_Technical_Structure }}$ http://learnrnd.com/detail.php?id=Types_of_Obesity_Its_Symptoms_and_Prevention http://learnrnd.com/detail.php?id=Age_Effects_on_Brain_with_Symptoms_and_their_Solutions http://learnrnd.com/detail.php?id=PAK-CHINA_ECONOMIC_CORRIDOR

\section{Results and Discussion}

\subsection{Synthesis and spectral characterization of ligand acid dyes and their metal complexes}

Synthesis of Acid dyes and their (Cr, III) complexes were achieved accordingly as represented in scheme 1. Reactant 1 was nitrosated at $0--5^{\circ} \mathrm{C}$ using $\mathrm{NaNO}_{2}$ and $\mathrm{HCl}$, and filtered to remove the remove the suspended impurities as described by Knorr. The clarified nitroso intermediate was salted out by common salt. Reduction of nitroso was carried at $100--105^{\circ} \mathrm{C}$ using Zinc and $\mathrm{HCl}$. The oxime and zinc dust were successively added in small portions in boiling $\mathrm{HCl}$ solution. A small amount of additional zinc dust was also added to prevent aerial oxidation on cooling. 


\section{ACCEPTED MANUSCRIPT}

$\mathrm{NaNO}_{2}\left(6.9 \mathrm{~g}\right.$ dissolved in $250 \mathrm{ml}$ of solution) and $\mathrm{HCl}$ at -5 to $-2^{\circ} \mathrm{C}$ to avoid the formation of Rubazoic acid, which results due to oxidizing action of nitrous acid, formed in situ. The diazonium salt prepared in this way was coupled with different para substituted phenols, like, $p$ Chlorophenol, $p$-Nitrophenol, phenol-4-suphonic acid, 2-Nitrophenol-4-suphonic acid and bisphenols (Bisphenol S and Bisphenol A). The coupling was carried out in alkaline medium at pH 8--9. The synthesis of this diazo has been confirmed from X-ray structure of its crystal. Coupling in alkaline medium occurred at ortho position to the hydroxyl groups of phenol and bisphenol derivatives, as para positions were blocked. The synthesized dyes 6 a-e were precipitated on completion of reaction by lowering the $\mathrm{pH}$ of solution to 1.0 with $\mathrm{HCl}$. The filtered dyes were dried and purified in ethanol. Metallization of these dyes was done by treating their alkaline solution with $\mathrm{Cr}\left(\mathrm{CH}_{3} \mathrm{COO}\right)_{3}$ at $65--70^{\circ} \mathrm{C}$. It took about 4--5 hours for completion of metallization which was observed by taking the TLC of reaction mixture in 9:1 chloroform and methanol. Dyes ( 7 a-f) were precipitated with addition of $\mathrm{HCl}$, filtered and dried in oven at $80^{\circ} \mathrm{C}$. These dyes were again recrystallized from ethanol, dried, weighed and calculated their percentage yield. These unmetallized dyes 6 a-e are tridentate ligands which formed complexes with Chromium (Cr, III) through 1:2 metal and ligand ratio. In Chromium (III) complexes lone pairs of electrons are donated by two oxygen atoms and one nitrogen atom of the diazo linkage. The complex formation pattern has been verified by the UV-visible spectrophotometric studies of these dyes 7 a-f. The infrared spectra of the synthesized acid dyes and their metal complexes exhibited IR absorption peaks due to $\mathrm{O}-\mathrm{H}, \mathrm{Ar}-\mathrm{H}, \mathrm{C}-\mathrm{H}, \mathrm{C}=\mathrm{O}, \mathrm{C}=\mathrm{C}, \mathrm{N}=\mathrm{N}, \mathrm{SO}_{3} \mathrm{H}, \mathrm{C}-\mathrm{O}$ and $\mathrm{O}-$ M stretching and bending vibrations at 3399, 3050, 2926, 1550, 1472, 1272, 1164, 1004, 834 


\section{ACCEPTED MANUSCRIPT}

$610 \mathrm{~cm}^{-1}$ as depicted from their FTIR spectra (Figure 1). Similarly other metal complexes have been confirmed from their respective IR spectra.

${ }^{1}$ H-NMR and ${ }^{13} \mathrm{C}$-NMR spectra were taken for ligand dyes which showed characteristic signals for different protons and carbons at different positions which evidenced the synthesis of dyes. In case of compounds $6 \mathrm{~b}$ signal for hydroxyl group was absent due to exchangeable proton with DMSO. The doublet signal of mutually coupled set of four protons of phenyl group substituted with sulfonic group at present 7.95 and 7.68 ppm having coupling constant respectively signals 8.6 $\mathrm{Hz}$. The multiplet signal for one proton of aromatic ring of coupling moiety is present at 7.83-7.90 $\mathrm{ppm}$ while the same ring bearing another single proton shows signal at $8.07 \mathrm{ppm}$ with coupling constant $2.35 \mathrm{~Hz}$ which evidenced the meta relationship with another proton at the same ring. The methyl group present at pyrazolone ring exhibited singlet signal at $2.20 \mathrm{ppm}$ (Figure 2). In ${ }^{13} \mathrm{C}$-NMR spectrum the signal for methyl group is present at $12.14 \mathrm{ppm}$. There are ten signals in the range 117.06-158.00 ppm for different carbon nuclei in the compound (Figure 3). In this way other ligand acid dyes were confirmed from their respective ${ }^{1} \mathrm{H}-\mathrm{NMR}$ and ${ }^{13} \mathrm{C}-\mathrm{NMR}$ spectra. When the ${ }^{1} \mathrm{H}-\mathrm{NMR}$ spectra of metal complexes were conducted but they showed very broad and distorted signals due to paramagnetic nature of Chromium used for complexation and the so the NMR study of complexes did not prove fruitful for structure elucidation but on the other hand distorted broad signals evidenced the complexation when the ${ }^{1}$ H-NMR of ligands acid dyes and complexes were compared.

3.2 Dyeing properties of substituted ligand acid dyes and their metal complexes ( 6 a-f and 7 a-f) 


\section{ACCEPTED MANUSCRIPT}

The dyeing properties of $p$-substituted phenols and bis phenol dyes have been found to be very attractive. Almost all properties have been found to be of very high value (4-5). Ligand dyes had low values as per our expectation due to the presence of free hydroxyl groups. The dyeing properties of these dyes are given in Table 2.

Almost all un-metalized $p$-substituted phenol dyes have been found to be different; both in $2 \%$ and $5 \%$ dyed leathers, along with a variation of depth of Shades. This can be attributed to the difference of chromophoric systems in all dyes. However, it is clear from shades that this difference is due to the difference of $p$-substituents in different phenols. All of the phenol homologues had dark and redder shades except $p$-sulphophenol substituted dyes. The variation of the depth can be attributed to the participation of peripheral group's variation in different phenols.

Almost all Chromium-metalized Phenol dyes had been found to be of Olive color; both in $2 \%$ and 5\% dyed leathers with a little variation of depth in Shades. All the phenol homologues had dark and redder shades except $p$-sulphophenol. Both nitro phenols had similar shades with yellowish tone. The dyeing properties of Bis-phenols dyes have been found to be very good and attractive. Almost all properties have been found to be of very high value (4-5).The dyes with Bisphenol-A has been found to be much darker as compared to the dyes of Bisphenol-S. This can be attributed to the $n \rightarrow \Pi^{*}$ electronic transitions occurring in sulphone group of Bisphenol-S.

http://learnrnd.com/detail.php?id=Pride_and_Prejudice_:Summary_and_Analytical_Review http://learnrnd.com/detail.php?id=TO_KILL_A_MOCKING_BIRD_Part_2:Complete_Analysis_and_R eview

As it is clear from dye shades among the un-metalized Bisphenol dyes, the dye with Bisphenol-A had a high color value while Bisphenol-S dye gave a low color yield on Leather. This difference can be ascribed to the participation of Sulphone group present in Bisphenol-S. 


\section{ACCEPTED MANUSCRIPT}

complex with ligand acid dye based on bisphenol-S had a low color value while bisphenol-A dye provided a darker shade and high color yield on leather along with a much redder effect. This difference can be attributed to the participation of sulphone group in bisphenol-S (Table 3 and 4).

\subsection{Optical Studies of Dyes}

In case of optical studies, dyes were conducted their UV-visible studies to observe the changes rendered by metal complex formation. The UV-visible data presented in table-2 is supported by combined UV-visible spectra of ligand acid dyes 6 a-f. The un-metalized dye- 6 a was an orange dye with $\lambda \cdot \max 460 \mathrm{~nm}$ while on metallization of this with Chromium Olive Brown dye (Dye-7 a) was produced with $\lambda \cdot \max 490 \mathrm{~nm}$ undergoing a bathochromic shift of $30 \mathrm{~nm}$ along with hypochromic effect.

The unmetallized dye $6 \mathrm{~b}$ was an Orange dye with $\lambda_{\max } 480 \mathrm{~nm}$ which developed $\tan /$ dye on complexation with chromium (Dye $7 \mathrm{~b}$ ) with $\lambda \cdot \max 500 \mathrm{~nm}$. It also showed bathochromic shift of $20 \mathrm{~nm}$ along with hyperchromic effect. Chromium (III) complexes of ligands 6 c and 6 d showed hypsochromic effect which is attributed to electron withdrawing groups attached to couplers.

In the bisphenol series two dyes were prepared. For this purpose two different Bisphenols, namely 4,4'-dihydroxy biphenyl sulphone (BPS), 4, 4'-dihydroxy biphenyl propane (BPA), were used as couplers. The un-metalized dye 6e was a Reddish Orange dye with $\lambda_{\max } 420 \mathrm{~nm}$ Its metallization with Chromium produced a Reddish brown dye (Dye 7i) with $\lambda_{\max } 430 \mathrm{~nm}$ and a red shift of $10 \mathrm{~nm}$ was seen. From the detailed UV-visible study of dyes it was gathered that metal complexes of ligand dyes bearing electron with drawing groups showed hypsochromic shit 


\section{ACCEPTED MANUSCRIPT}

and those having electron donating groups showed bathochromic shift in absorbance which is in accordance with well-established UV-visible absorption pattern of compounds (Figure 5 and 6). This UV-visible also established the octahedral geometry for the synthesized metal complexes [Yildiz 2013].

\subsection{DNA Binding Studies.}

The binding Characteristics of metal complexes with DNA can be emphasized by employing electronic spectroscopy (Table, 5). The absorption spectra of some representative metal complexes $7 \mathrm{a}, 7 \mathrm{~b}, 7 \mathrm{~d}$ and $7 \mathrm{f}$ in the presence and absence of SS Fish Salmon Sperm shown in figure 7. In UV and visible region, the intense band at $370 \mathrm{~nm}$ attributed to the ligand to metal charge transfer absorption and another at $265 \mathrm{~nm}$ which is assigned to the $\pi-\pi^{*}$ transition of aromatic chromophore. Polarity of the ligand, coordination geometry, ligand donor atom type and metal ion type (Jayaseelan et al, 2011) dictate the chelating ability of the complex. Strong stacking interaction between an aromatic chromophore and the base pairs of DNA results in the Red shift while the cause of hypochromism is intercalative mode of DNA binding. Similarly the hyperchromism is actually due to non-intercalative or electrostatic mode of DNA binding.

Strong $\pi$ - $\pi^{*}$ stacking interaction between the aromatic chromophore ligand of metal complex and base pairs of DNA exhibit significant hypochromism and red shift (Terenzi et al, 2009). Intercalative binding between DNA and metal complex is responsible in hypochromism with slight red shift (Bathochromic shift).

By increasing the concentration $10 \% \mathrm{M}$ to $100 \mu \mathrm{M}$ at lambda shift to red/blue nearly 3,3,2,2 nm respectively (Colak et al, 2010). 


\section{ACCEPTED MANUSCRIPT}

\section{Conclusions}

New acid dye ligands and their Chromium (III) complexes based on 4-Amino-1-( $p$ sulphophenyl)-3-methyl-5-pyrazolone diazonium salt and phenolic couplers were prepared and characterized by physico-chemical methods. The octahedral geometry was observed by UV visible spectrophotometric studies and was attributed to $\mathrm{Cr}$ (III) coordination with nitrogen of azo group and oxygen of pyrazolone ring hydroxyl groups. The DNA binding studies showed that metal complexes have good binding constant and spontaneity as compared to ligands and intercalation DNA binding mode was observed as shown in table 5. 


\section{ACCEPTED MANUSCRIPT}

\section{References.}

1. Kamellia, N.; Zolfaghar, R.; Masoud, S. The synthesis, characterization, thermal and optical properties of nickel, and vanadyl complexes derived from azo dyes. Dyes and Pigments. 2009, $83,304--311$.

2. Vulpes, D.; Chiriac, A. Synthesis and spectroscopic properties of new pyrimidinic azo-dyes. Series of Chemistry. 2008, 18, 53--60.

3. Mohamed, G.; Yusif, S. E.; Kamal, E.; Rowaida, M. F. Cu (II) complexes of monobasic bi- or tridentate (NO, NNO) azo dye ligands: Synthesis, characterization, and interaction with $\mathrm{Cu}-$ nanoparticles. Journal of Molecular structure. 2013, 1032, 185--194.

4. Khalid, J.; Al-Adilee.; Ahmed, K.; Abbas, A. Synthesis of some transition metal complexes with new heterocyclic thiazolyl azo dye and their uses as sensitizers in photo reactions. J. of Mol. Struc. 2016, 1108, 378--397.

5. Munire, S.; Aysel, S.; Muhammet, K.; Vickie, M.; Mefuz, E.; Ibrahim, D.; Mukerrem, K. Inorganica chimica Acta. 2016, 444, 166--175.

6. Ghulam, S.; Aamer, S. Solvent free one pot synthesis of symmetric xenthene dyes and their electrochemical study. J. Chil. Chem. Soc. 2016, 62.

7. Odabaşoglu, M.; Albayrak, C.; Ozkanca, R.; Aykan, F.Z.; Lonecke, P. Some polyhydroxy azo-azomethine derivatives of salicylaldehyde: Synthesis, characterization, spectroscopic, molecular structure and antimicrobial activity studies. J. of Mol. Struc. 2007, 840, 71--89. 


\section{ACCEPTED MANUSCRIPT}

8. Bin, W.; Yi-Qun, W.; Dong-Hong, G.; Fu-Xi, G. Optical parameters and absorption of azo dye and its metal-substituted compound thin films. Chinese physics letters. 2003, 20, 1596.

9. Covaci, A.; Dirtu, A. C.; Voorspoels, S.; Roosens, L.; Lepom, P. Sample preparation and chromatographic methods applied to congener-specific analysis of polybrominated diphenyl ethers." Brominated Flame Retardants. 2010, Springer Berlin Heidelberg 55--94.

10. El-Wakiel, N.; El-Sayed, Y.; Gaber, M.; Synthesis, characterization, and theoretical studies of $\mathrm{Co}$ (II) and $\mathrm{Cu}$ (II) complexes of 1-[(5-mercapto-[1, 3, 4] thiadiazol-2-ylimino)-methyl]naphthalen-2-ol and its interaction with Cu nanoparticles. Journal of Molecular Structure.

2011, 1001, 1--11.

11. Abuthahir, S.S.S.; Nasser, A. J. A.; Rajendran, S.; Brindha, G. Synthesis, spectral studies and antibacterial activities of 8-hydroxyquinoline derivatives and its metal complexes. Chem. Sci. Transf. 2014, 3, 303--313.

12. Al-Adilee, K.J.; Abass, A.K.; Taher, A.M. Synthesis of some transition metal complexes with new heterocyclic thiazolyl azo dye and their uses as sensitizers in photo reactions. Journal of Molecular Structure. 2016, 1108, 378--397.

13. Patel, D.R.; Patel, N.B.; Patel, B. M.; Patel, K.C. Synthesis and dyeing properties of some new monoazo disperse dyes derived from 2-amino-4-(2', 4'-dichlorophenyl)-1, 3 thiazole. Journal of Saudi Chemical Society. 2014, 18, 902--913. 


\section{ACCEPTED MANUSCRIPT}

14. Kurtoglu, G.; Avar, B.; Zengin, H.; Kose, M.; Sayin, K.; Kurtoglu, M. A novel azoazomethine based fluorescent dye and its $\mathrm{Co}$ (II) and $\mathrm{Cu}$ (II) metal chelates. Journal of Molecular Liquids. 2014, 200, 105--114.

15. Eren, T.; Kose, M.; Kurtoglu, N.; Ceyhan, G.; McKee, V.; Kurtoglu, M. An azo-azomethine ligand and its copper (II) complex: Synthesis, X-ray crystal structure, spectral, thermal, electrochemical and photoluminescence properties. Inorganica chimica Acta. 2015, 430, 268-279.

16. Yildiz, E.; Keles, M.; Kaya, A.; Dincer, S. Mononuclear Fe(III), Cr(III), Co(II) Metal complexes based on azo-anthraquinone moieties: Synthesis, Characterization and antibacterial activities. Chemical Science Transactions. 2013, 2(2), 547--555. 


\section{ACCEPTED MANUSCRIPT}

Table-1; Fastness properties of ligand acid dyes ( 6 a-f) and their metal complexes ( 7 a-f)

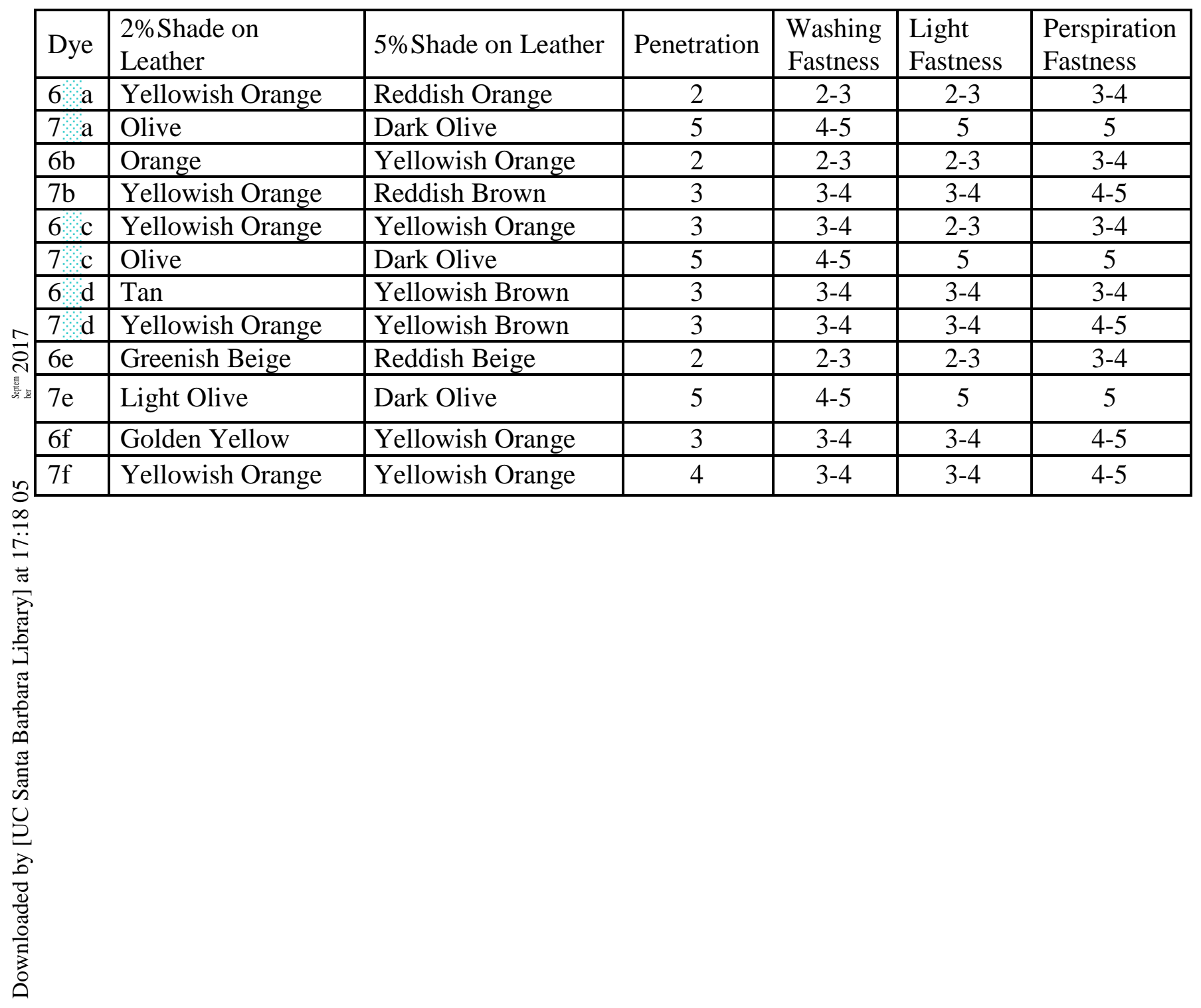




\section{ACCEPTED MANUSCRIPT}

Table-2; Dyeing properties of ligand acid dyes (6 a-f)

\begin{tabular}{|c|c|c|c|c|c|c|c|}
\hline \multicolumn{2}{|l|}{ Dyes } & $6, \mathrm{a}$ & $6 b$ & $6 \quad c$ & $6 \quad \mathrm{~d}$ & $6 e$ & $6 f$ \\
\hline \multirow{2}{*}{$\begin{array}{l}\text { Shades } \\
\text { on } \\
\text { Leather }\end{array}$} & $\begin{array}{l}2 \% \\
\text { Shade }\end{array}$ & & & & & & \\
\hline & $\begin{array}{l}5 \% \\
\text { Shade }\end{array}$ & & & & & & \\
\hline
\end{tabular}




\section{ACCEPTED MANUSCRIPT}

Table-3; Dyeing properties of Chromium complex dyes ( 7 a-f)

\begin{tabular}{|c|c|c|c|c|c|c|c|}
\hline Dyes & & $7 \mathbf{a}$ & $7 b$ & $7 \mathrm{c}$ & $7 \mathrm{~d}$ & $7 e$ & $7 f$ \\
\hline $\begin{array}{l}\text { Shades } \\
\text { on }\end{array}$ & $\begin{array}{l}2 \% \\
\text { Shade }\end{array}$ & & & & & & \\
\hline Leather & $\begin{array}{l}5 \% \\
\text { Shade }\end{array}$ & & & & & & \\
\hline
\end{tabular}




\section{ACCEPTED MANUSCRIPT}

Table-4, UV-Visible data of ligand acid dyes (6 a-f) and their Cr (III) complexes (7 a-f)

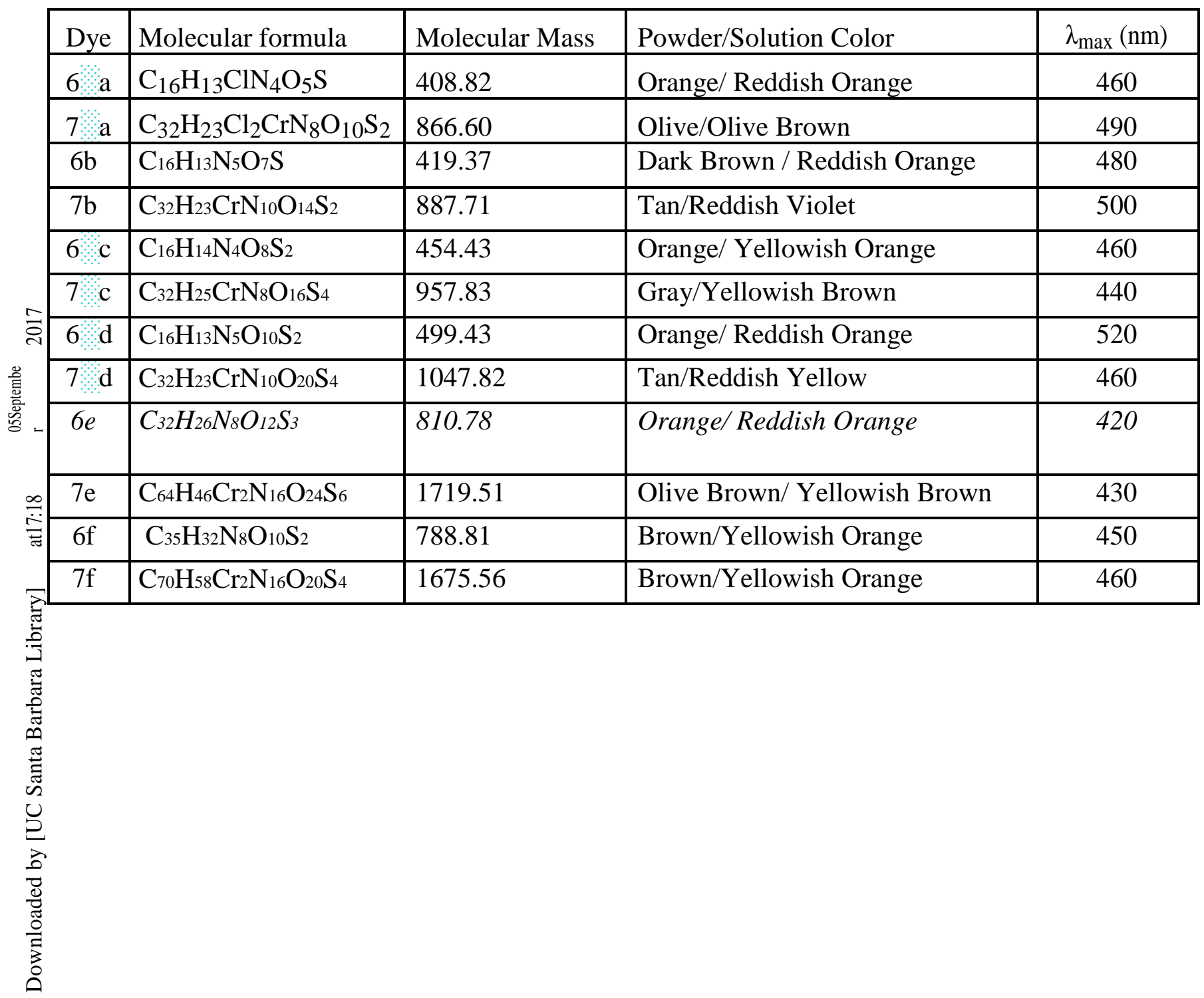




\section{ACCEPTED MANUSCRIPT}

Table-5, data of ligand acid dyes (6,a-f) and their $\mathrm{Cr}$ (III) complexes (7 a-f)

\begin{tabular}{|l|l|l|l|l|l|}
\hline $\begin{array}{l}\text { Sample } \\
\text { Code }\end{array}$ & $\lambda \cdot \max (\mathbf{n m})$ & $\begin{array}{l}\text { Absorption } \\
\text { of Free } \\
\text { Complex }\end{array}$ & $\begin{array}{l}\text { Absorption } \\
\text { with DNA }\end{array}$ & $\begin{array}{l}\text { Binding } \\
\text { Constant }(\mathbf{K J} \\
\text { mol }^{-1}\end{array}$ & $\begin{array}{l}\text { Wavelength } \\
\text { Shift(nm) }\end{array}$ \\
\hline $\mathbf{7} \mathbf{a}$ & 464 & 0.603 & 0.556 & -24.77 & 3 \\
\hline $\mathbf{7 b}$ & 483 & 1.142 & 0.960 & -29.80 & 3 \\
\hline $\mathbf{7} \mathbf{c}$ & 489 & 1.521 & - & - & - \\
\hline $\mathbf{7} \mathbf{d}$ & 505 & 0.692 & 0.615 & -29.82 & 2 \\
\hline $\mathbf{7 e}$ & 584 & 0.101 & - & - & - \\
\hline $\mathbf{7 f}$ & 479 & 0.437 & 0.386 & -29.82 & 2 \\
\hline
\end{tabular}




\section{ACCEPTED MANUSCRIPT}

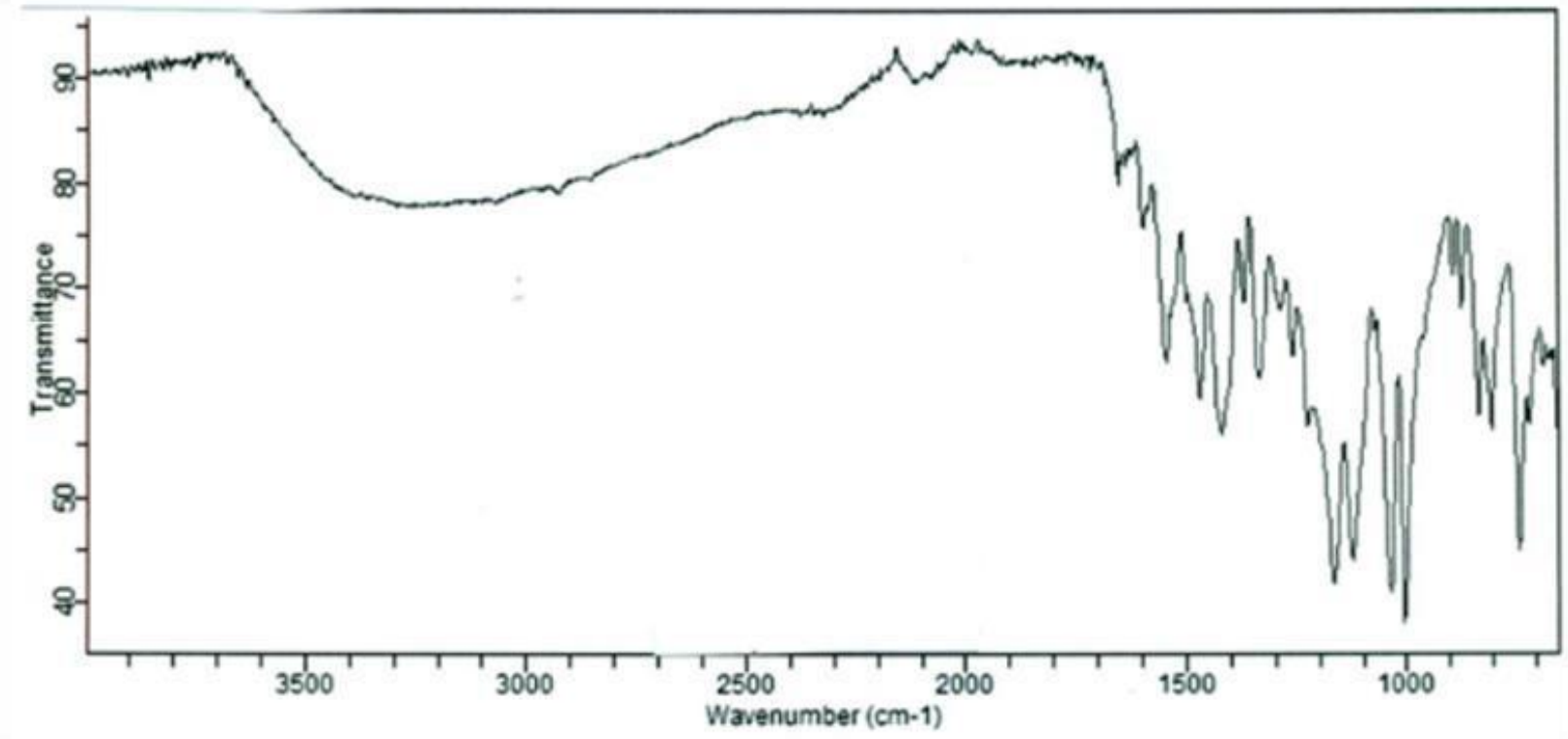

Figure 1, FTIR spectrum of Chromium complex of dye 6b. 


\section{ACCEPTED MANUSCRIPT}

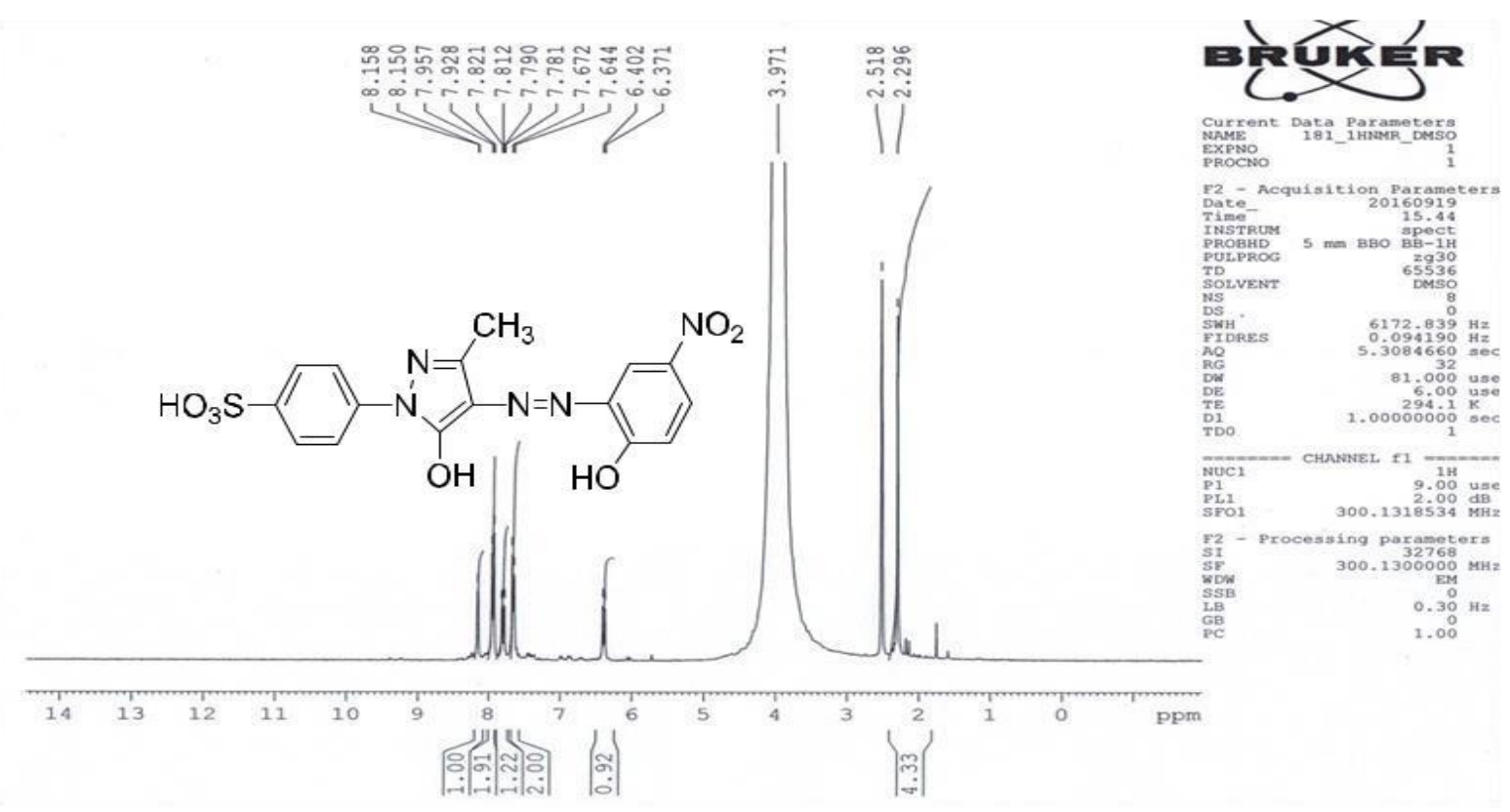

Figure 2, ${ }^{1} \mathrm{H}-\mathrm{NMR}$ spectrum of ligand acid dye $6 \mathrm{~b}$. 


\section{ACCEPTED MANUSCRIPT}

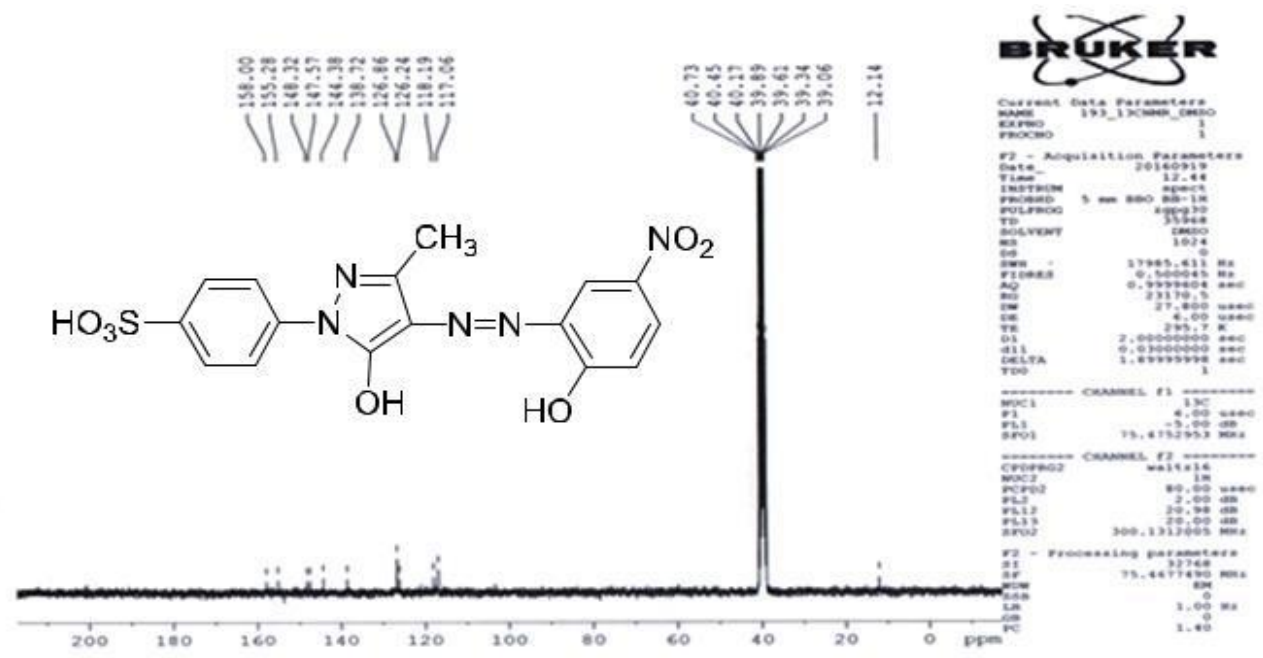

Figure $3,{ }^{13} \mathrm{C}-\mathrm{NMR}$ spectrum of ligand acid dye $6 \mathrm{~b}$. 


\section{ACCEPTED MANUSCRIPT}
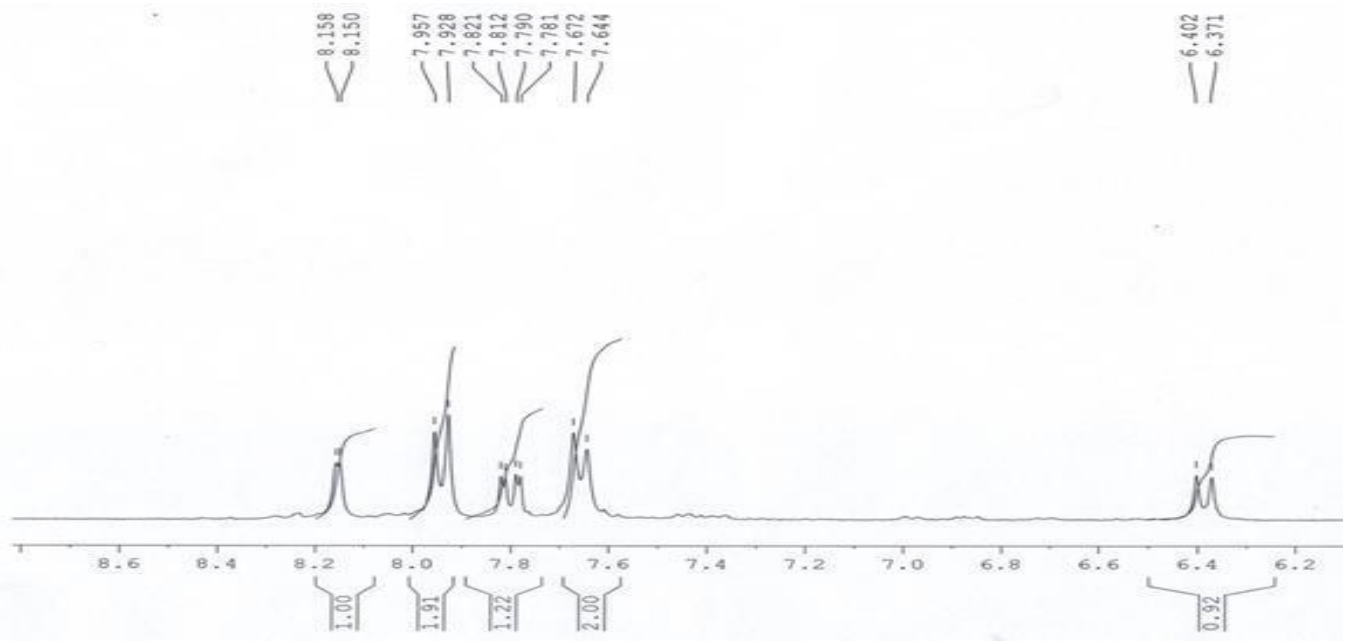

Figure 4, Expanded $\mathrm{H}^{1}$-NMR of Ligand acid dye $6 \mathrm{~b}$. 


\section{ACCEPTED MANUSCRIPT}

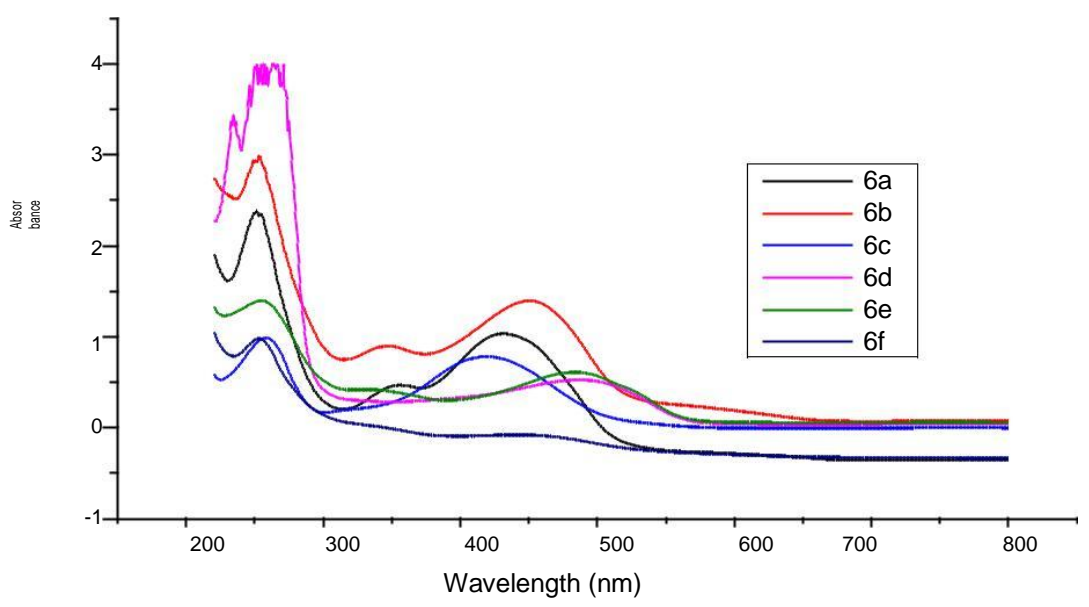

Figure 5, UV-Visible spectrum of ligand acid dyes 6 a-f. 


\section{ACCEPTED MANUSCRIPT}

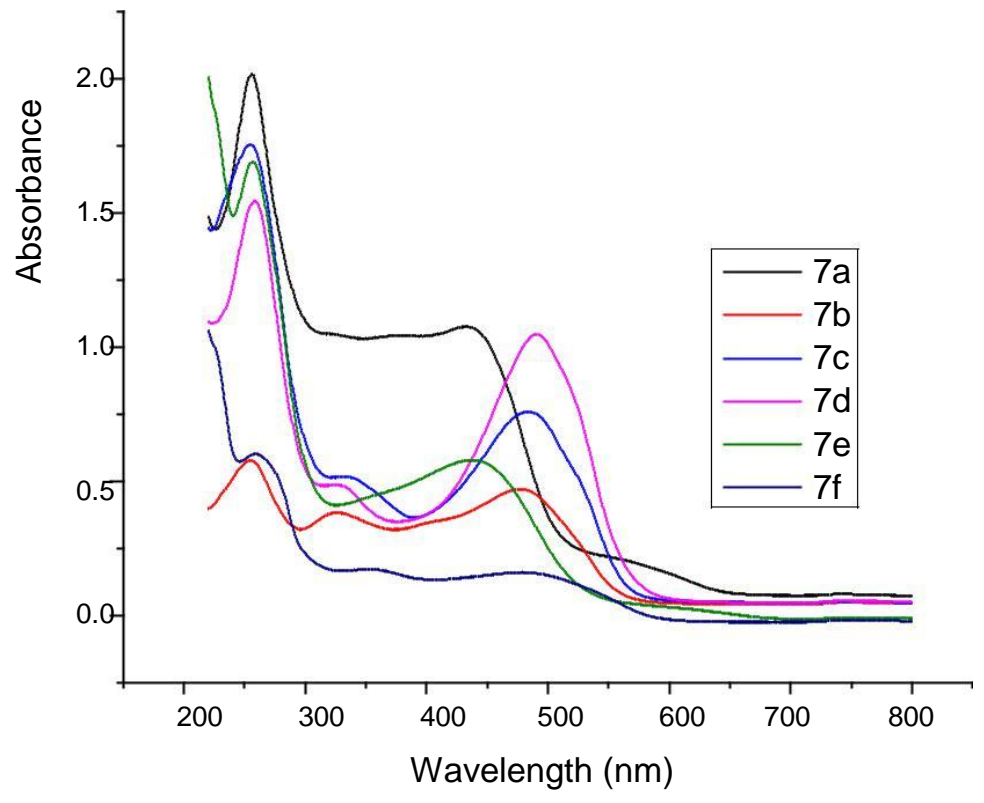

Figure 6, UV-Visible spectrum of Chromium (III) complex dyes 7 a-f. 


\section{ACCEPTED MANUSCRIPT}
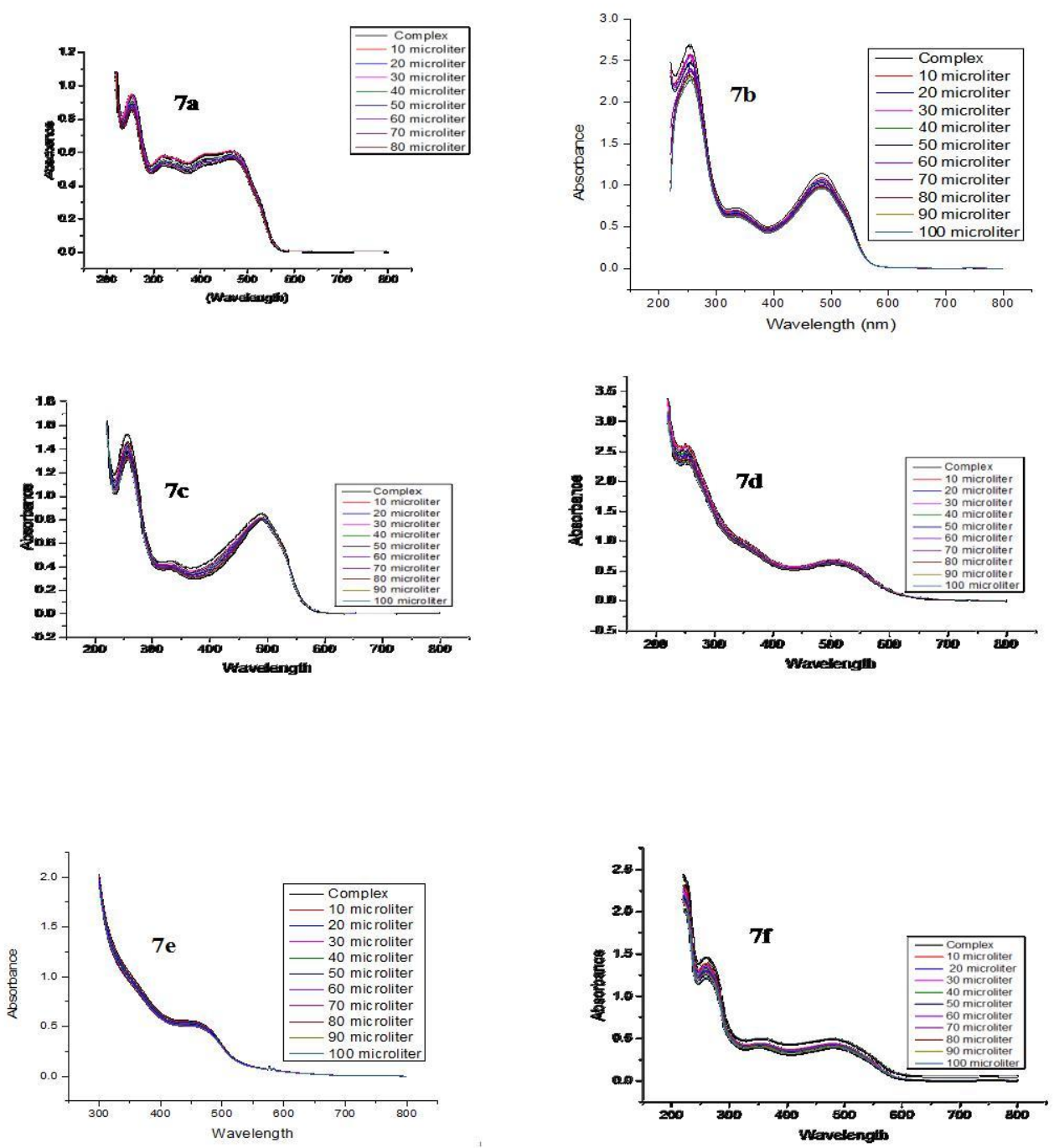

Figure 7, DNA binding studies of Chromium (III) complex dyes 7 a-f. 


\section{ACCEPTED MANUSCRIPT}

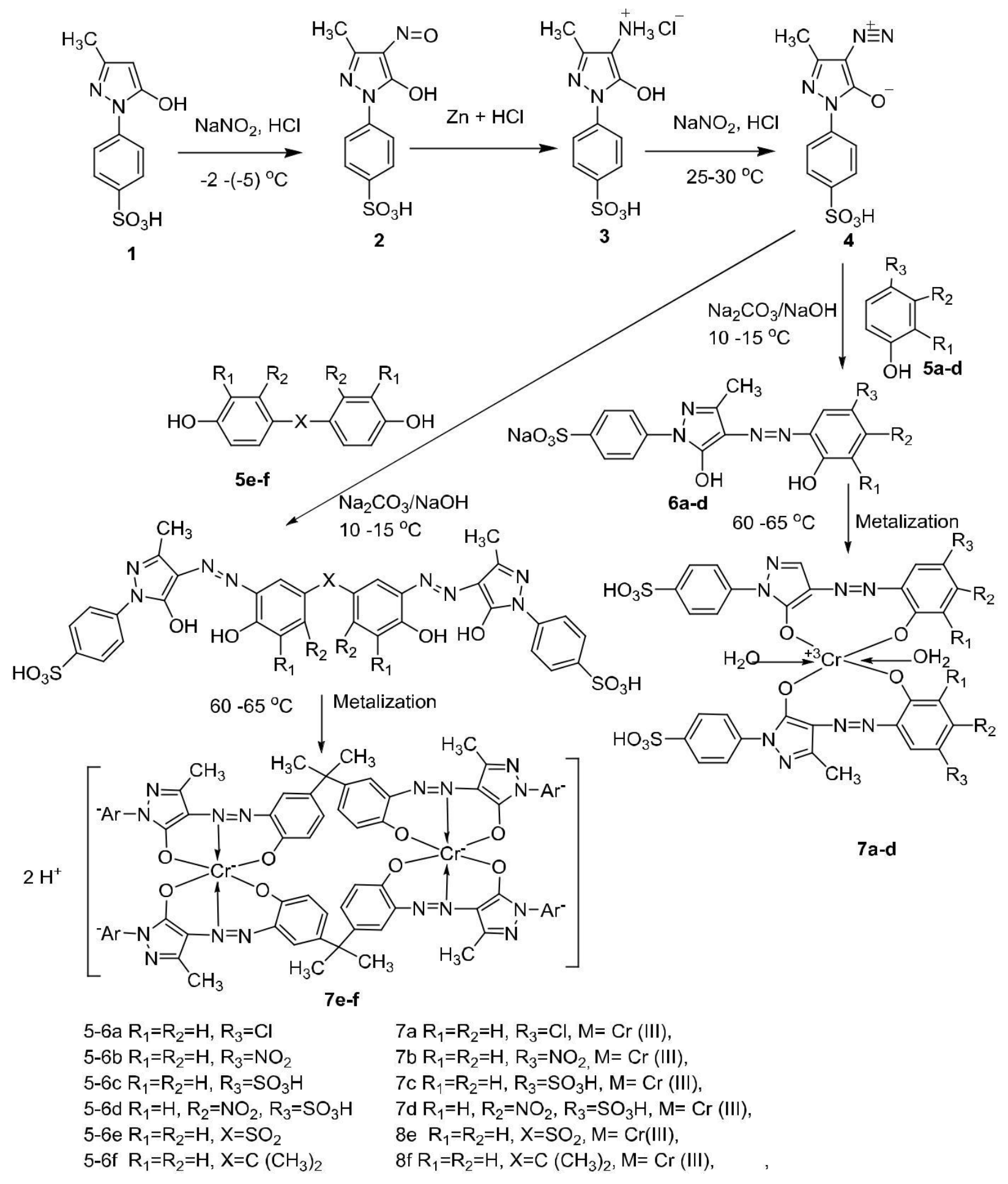

Scheme 1, Synthesis of ligand acid dyes and their Cr (III) complexes (7 a-f) 